\title{
Adaptability and genotypic stability of Coffea arabica genotypes based on REML/BLUP analysis in Rio de Janeiro State, Brazil
}

\author{
W.P. Rodrigues ${ }^{1}$, H.D. Vieira ${ }^{1}$, D.H.S.G. Barbosa ${ }^{2}$, G.R. Souza Filho ${ }^{1}$ and \\ L.S. Candido ${ }^{3}$ \\ ${ }^{1}$ Laboratório de Fitotecnia, \\ Universidade Estadual do Norte Fluminense Darcy Ribeiro, \\ Campos dos Goytacazes, RJ, Brasil \\ ${ }^{2}$ Embrapa Mandioca e Fruticultura, Cruz das Almas, BA, Brasil \\ ${ }^{3}$ Laboratório de Melhoramento Genético Vegetal, \\ Universidade Federal da Grande Dourados, \\ Dourados, MS, Brasil \\ Corresponding author: W.P. Rodrigues \\ E-mail: wevertonuenf@hotmail.com
}

Genet. Mol. Res. 12 (3): 2391-2399 (2013)

Received October 3, 2012

Accepted January 16, 2013

Published July 15, 2013

DOI http://dx.doi.org/10.4238/2013.July.15.2

\begin{abstract}
Biannuality in coffee culture causes temporal variability in plant productivity. Consequently, it is essential to evaluate genotypes during various crop years to ensure selection of productive and stable genotypes. We evaluated the effectiveness of simultaneous selection of coffee genotypes along harvests, based on productivity, stability, and adaptability, via mixed models, for indication of varieties suitable for Rio de Janeiro State. We evaluated 25 genotypes during 4 crop seasons (2009-2012), in a randomized block design with 5 replications. The ranking of genotypes was obtained on the basis of the adaptability and temporal stability methods (harmonic average of genetic values, relative performance of genetic values, and harmonic mean of the relative performance of the genetic values), obtained via restricted maximum likelihood/best linear unbiased procedure analysis. The selection accuracy
\end{abstract}


(0.8717), associated with the high magnitude of mean heritability, indicate good reliability and prospects for success in the indication of agronomically superior genotypes. There was little variation in the ordering of genotypes among the environments, indicating low influence of harvests in the performance of the genotypes. Five of the 25 genotypes were superior and could be recommended for planting in the northwestern region of Rio de Janeiro State, due to high predicted productivity and stability. We recommend that these methodologies for evaluation of productivity, stability, and adaptability be included in the selection criteria for recommendation of genotypes for commercial plantings.

Key words: Coffee; Genetic value; Harvests

\section{INTRODUCTION}

Rio de Janeiro State, Brazil, which was once the largest national producer of coffee, currently ranks seventh with a production of 250.1 thousand $60-\mathrm{kg}$ bags, including 237,600 bags of arabica coffee and 12,500 bags of conilon coffee, and has a growing area of 13,250 hectares (Companhia Nacional de Abastecimento, 2012). However, Rio de Janeiro still shows promise for the expansion of the crop, since the consumption of coffee in this State is 1.3 million bags for year, which corresponds to $10 \%$ of Brazilian domestic consumption (Centro do Comércio de Café do Rio de Janeiro, 2012).

In addition to plant health problems such as Hemileia vastatrix Berk. and $\mathrm{Br}$. and Meloidogyne exigua (Goeldi, 1887), the maintenance of old and depleted crops and mainly the lack of compatible technologies, such as the planting of genetically improved cultivars, contributed to the decline of the crop in the State.

However, through genetic improvement, several varieties of coffee were launched providing increased productivity, quality, and/or resistance to pests and diseases. However, since coffee-growing regions in Brazil show different climatic conditions, the responses of cultivars are usually not the same in these environments and even in different harvests, due to what we know as genotype (G) x environment (E) interactions (Cucolotto et al., 2007). Coffee is susceptible to aggravating circumstances because of being a biennial crop, in which there is temporal variability in the productivity of plants during different harvests. Thus, studies are needed to evaluate the responses of coffee cultivars in different harvests in the coffee-growing regions of the country, especially in Rio de Janeiro State.

In this sense, the study of the G x E interaction combining analyses of stability and adaptability through the mixed model restricted maximum likelihood/best linear unbiased prediction (REML/BLUP) has been used successfully, mainly in perennial crops (Maia et al., 2009; Rosado et al., 2012).

The individual BLUP is suitable for prediction of genetic values consisting basically of a random-effect statistical model associated with phenotypic observations, by adjusting the data to the fixed effects and the uneven amount of information on the plots, when this is the case. In this way, the best interpretations are obtained about the performance of a particular genotype compared to environmental variations, ensuring a high degree of reliability in the recommendation for a particular environment, minimizing future risks that may cause losses to producers (Resende, 2002). 
The harmonic mean of the genetic values (MHVG), the relative performance of the genetic values (PRVG), and the harmonic mean of the relative performance of the predicted genetic values (MHPRVG) are methods for assessment of stability and adaptability genotypic through the REML/BLUP procedure proposed by Resende (2007). Using selection criteria for productivity, stability, and adaptability, these methods contributed to the increase in the efficiency in breeding programs for selection and recommendation of genetic material for cultivation in different edaphoclimatic conditions (Verardi et al., 2009).

The aim of this study was to determine the effectiveness of simultaneous selection of genotypes of coffee in different harvests, based on productivity, stability, and adaptability, through mixed models, to indicate one or more plant varieties for Rio de Janeiro State.

\section{MATERIAL AND METHODS}

The experiment was initiated in February 2007 on Panorama 1 Farm, located in the municipality of Varre e Sai, in the northwestern Rio de Janeiro State. The soil is classified as red yellow latosol and the climate is typical of high tropics, with cool summers and colder winters and with an average annual temperature of $19.0^{\circ} \mathrm{C}$ and $1601 \mathrm{~mm}$ for an average annual precipitation (Martorano et al., 2003).

The 25 genotypes evaluated (Table 1) were grown with a spacing of $2.5 \times 0.8 \mathrm{~m}$, in a randomized block design, with 5 replications, containing 8 plants each. The crops were evaluated in 2009, 2010, 2011, and 2012, where they were harvested on cloth, when the plants had 80 ripe fruits (cherries). The collected volume was converted to bags processed/ ha (bags/ha) using the scale of $480 \mathrm{~L}$ coffee cherries per $60-\mathrm{kg}$ bag processed, accounting for productivity.

Table 1. Origin and provenience of the Coffea arabica genotypes evaluated.

\begin{tabular}{rlll}
\hline No. & Genotype & Origin & Provenience \\
\hline 1 & Catucaí Vermelho 785/15 & Icatu Vermelho x Catuaí Amarelo & PROCAFÉ \\
2 & Catucaí Amarelo 2 SL & Icatu Vermelho x Catuaí Amarelo & PROCAFÉ \\
3 & IPR/Iapar & Villa Sarchi x Híbrido do Timor & IAPAR \\
4 & Catiguá MG 02 & Catuaí Amarelo 86 x Híbrido do Timor & EPAMIG \\
5 & IPR 99/Iapar & Villa Sarchi x Híbrido do Timor & IAPAR \\
6 & Acauã & Mundo Novo 388-17 x Sarchimor 1668 & PROCAFÉ \\
7 & Araponga MG 01 & Catuaí Amarelo 86 x Híbrido do Timor & EPAMIG \\
8 & Palma II & Catuaí x Catimor & IBC \\
9 & Sabiá 398 & Acaiá x Catimor & PROCAFÉ \\
10 & IPR 103/Iapar & Icatu x Catuaí & IAPAR \\
11 & IPR 100/Iapar & Villa Sarchi x Híbrido do Timor & IAPAR \\
12 & H 4193-3-3-716-4-1 & Catuaí Amarelo x Híbrido do Timor & EPAMIG \\
13 & H 419-10-6-2-12-1 & Catuaí Amarelo x Híbrido do Timor & EPAMIG \\
14 & Catucaí Amarelo 24/137 & Icatu Vermelho x Catuaí Vermelho & PROCAFÉ \\
15 & Iapar 59 & Villa Sarchi x Híbrido do Timor & IAPAR \\
16 & Oeiras & Seleção de Catimor & EPAMIG \\
17 & Catuaí Vermelho144 & Caturra Amarelo 7476 x Mundo Novo 374 & IAC \\
18 & Catucaí Amarelo 20/15 & Icatu Vermelho x Catuaí Vermelho & PROCAFÉ \\
19 & Catiguá MG 01 & Catuaí Amarelo 86 x Híbrido do Timor & UFV \\
20 & H 419-10-6-2-5-10-1 & Catuaí Amarelo x Híbrido do Timor & EPAMIG \\
21 & IPR 104/Iapar & Villa Sarchi x Híbrido do Timor & IAPAR \\
22 & Sacramento MG 01 & Catuaí Vermelho 81 x Híbrido do Timor & EPAMIG \\
23 & Bourbon Amarelo LCJ 10 & Bourbon Vermelho x Amarelo de Botucatu & IAC \\
25 & Pau Brasil & Catuaí Vermelho 141 x Híbrido do Timor & EPAMIG \\
\hline & H 419-10-6-2-5-1 & Catuaí Amarelo x Híbrido do Timor & EPAMIG \\
\hline
\end{tabular}


Estimates of genetic parameters were obtained on the basis of the REML/BLUP procedure, using the statistical model 55 of the Selegen software (Resende, 2007), given by y $=$ $\mathrm{Xm}+\mathrm{Zg}+\mathrm{Wp}+\mathrm{Ti}+\mathrm{e}$, where $y$ is the vector data, $m$ is the vector of effects of measurementrepeating combinations (assumed to be fixed) added to the overall average, $g$ is the vector of the genotypic effects (assumed to be random), $p$ is the vector of the permanent environment effect (in this case, random plots), $i$ is the vector of the effects of the genotypes $\mathrm{x}$ measurements interaction, and $e$ is the vector of errors or waste (random). The letters represent the incidence matrices for these purposes. The following are the mixed model equations:

$$
\left[\begin{array}{ccc}
X^{\prime} X & X^{\prime} Z & X^{\prime} W \\
Z^{\prime} X & Z^{\prime} Z+I \lambda_{I} & Z^{\prime} W \\
W^{\prime} X & W^{\prime} Z & W^{\prime} W+I \lambda_{I}
\end{array}\right]\left[\begin{array}{l}
\mathrm{b} \\
\hat{g} \\
\hat{c}
\end{array}\right]=\left[\begin{array}{c}
X^{\prime} y \\
Z^{\prime} y \\
W^{\prime} y
\end{array}\right]
$$

where $I_{1}=\frac{s_{\theta}^{2}}{s_{g}^{2}}=\frac{1-h_{g}^{2}-c^{2}}{h_{g}^{2}} ; I_{2}=\frac{s_{\theta}^{2}}{s_{c}^{2}}=\frac{1-h^{2} g^{-c^{2}}}{c^{2}}$ in that:

$\mathrm{h}_{\mathrm{g}}^{2}=x=\frac{\mathrm{s}_{g}^{2}}{\mathrm{~s}_{g}^{2}+\mathrm{s}_{c}^{2}++s_{\theta}^{2}}=$ individual heritability in the broad sense of the block;

$\mathrm{c}_{\mathrm{g}}^{2}=x=\frac{\mathrm{s}_{c}^{2}}{\mathrm{~s}_{\mathrm{g}}^{2}+\mathrm{s}_{c}^{2}++\mathrm{s}_{\mathrm{e}}^{2}+}=$ determination coefficient of the effects of $\mathrm{G} x$ E interaction;

$\mathrm{s}_{\mathrm{g}}^{2}=$ genotypic variance between the genotypes;

$\mathrm{s}^{2}{ }_{\mathrm{c}}=$ variance of $\mathrm{G} \times \mathrm{E}$ interaction;

$\mathrm{s}_{\mathrm{e}}^{2}=$ experimental variance among plots;

$\hat{\mathrm{r}}_{\text {gloc }}=$ genotypic correlation of genetic materials, through environments.

This mixed thrifty model, of the main effects $(\mathrm{G})$ and interaction $(\mathrm{G} \times \mathrm{E})$, reproduces, approximately, through G + GE, the results of the BLUP multivariate model (Resende, 2004). The BLUP of the effects $\mathrm{G} \times \mathrm{E}$ eliminates inaccurate information of $\mathrm{G} \times \mathrm{E}$ interaction. This can be verified when considering that the BLUP prediction is obtained from a double-entry table, with genotypes (g) and environment (e) containing the averages of each genotype in each environment.

The model associated with this table can be described as:

$$
Y_{i j}=\mu+g_{i}+e_{j}+g_{i j}+e_{i j}=\bar{Y}+\left(-\bar{Y}_{i}-\bar{Y}\right)+\left(-\bar{Y}_{j}-\bar{Y}\right)+\left(\bar{Y}_{i j}-\bar{Y}_{i}-\bar{Y}_{j}+\bar{Y}\right)+e_{i j} ;
$$

in that $e_{i j}$ is the residue associated with the average, in each environment. The BLUP prediction of genotypic mean, at each site $\left(\mu+g_{i}+e_{j}+g_{i j}\right)$, is given by:

$$
I=\bar{Y}_{j}+h_{g}^{2}\left(\bar{Y}_{i}-\bar{Y}\right)+h_{g}^{2}\left(\bar{Y}_{j}-\bar{Y}_{i}-\bar{Y}_{j}+\bar{Y}\right)
$$


when considering the effects of environment as fixed (mixed model). The weights of the indices are:

$\mathrm{h}_{\mathrm{g}}^{2}=\left(\mathrm{s} \underset{g}{2}+\mathrm{s} \underset{g e^{2}}{2} / \mathrm{L}\right) /\left(\mathrm{s}_{g}^{2}+\mathrm{s}_{g}^{2} / \mathrm{L}+\mathrm{s} \underset{e}{2} / \mathrm{L}_{2}\right)$, heritability of the effects of genotypes;

$\mathrm{h}_{\mathrm{ge}}^{2}=\mathrm{s}_{g e}^{2} /\left(\mathrm{s}_{g}^{2}+\mathrm{s}_{e}^{2}\right)$, heritability of effects $\mathrm{G} \times \mathrm{E}$ interaction; and

$\mathrm{h}_{\mathrm{e}}^{2}=\left(\mathrm{s}_{e}^{2}+\mathrm{s} \underset{g e}{2} / \mathrm{L}\right) /\left(\mathrm{s}_{e}^{2}+\mathrm{s}_{g e}^{2} / \mathrm{G}+\mathrm{s}_{e}^{2} / \mathrm{G}\right)$, determination coefficient.

$G$ and $L$ refer to numbers of genotypes and locations, respectively, and $S$ to the residual variance associated with the average.

The selection of superior genotypes was based on the MHPRVG method for 3 strategies: selection based on predicted genetic value, having considered the average performance in all harvests (no interaction effect); selection based on predicted genetic value, having considered the performance of the genotypes in each crop (with average interaction effect); and simultaneous selection for production, stability (MHVG), and adaptability (PRVG).

\section{RESULTS AND DISCUSSION}

Heritability is an important genetic parameter that quantifies the fraction of phenotypic variance that is inheritable, i.e., genotypic nature. The heritability obtained in this study is considered to be of high magnitude (0.7598), which indicates high genetic control on the productivity of genotypes. Thus, there is great potential for selection and recommendation of productive coffee genotypes in this experiment. However, the individual heritability in the broad sense, relatively low (Table 2) is considered normal in the case of perennial crops, such as coffee. In relation to the genetic coefficient of variation, the high magnitude of the observed value characterizes the existence of genetic variability between genotypes, confirming the hypothesis that the greater part of the total variation is due to genetics.

\begin{tabular}{|c|c|c|c|}
\hline Genetic parameters & Estimates & Genetic parameters & Estimates \\
\hline $\mathrm{s}_{\mathrm{g}}^{2}$ & 34.9014 & $\hat{\mathbf{r}}_{g \widehat{g}}$ & 0.8717 \\
\hline $\mathrm{s}^{2}{ }_{\mathrm{c}}$ & 2.7937 & $\mathrm{c}^{2} \mathrm{~g}$ & 0.0115 \\
\hline $\mathrm{s}_{\mathrm{e}}^{2}$ & 205.03 & $\hat{\mathbf{r}}_{\text {gloc }}$ & 0.9259 \\
\hline$s^{2}{ }_{f}$ & 243.1389 & $\mathrm{CV}_{g} \%$ & 14.418 \\
\hline$h^{2}{ }_{g}$ & $0.1435 \pm 0.0479$ & $\mathrm{CV}_{e} \%$ & 15.7067 \\
\hline $\mathrm{h}_{\mathrm{mc}}^{2}$ & 0.7598 & MG & 40.9742 \\
\hline
\end{tabular}

$\mathrm{s}^{2}{ }_{\mathrm{g}}=$ genotypic variance between the genotypes; $\mathrm{s}^{2}=$ variance of genotype $\mathrm{x}$ environment $(\mathrm{G} \times \mathrm{E})$ interaction; $\mathrm{s}^{2}{ }_{\mathrm{e}}=$ experimental variance among plots; $\mathrm{s}_{\mathrm{f}}^{2}=$ individual phenotypic variance; $\mathrm{h}_{\mathrm{g}}^{2}=$ individual heritability in the broad sense of the block; $\mathrm{h}^{2}$ mc $=$ average heritability of genotypes; $\hat{\mathrm{r}}_{g \hat{g}}=$ accuracy in selecting genotypes; $\mathrm{c}^{2}=$ determination coefficient of the effects of G x E interaction; $\hat{\mathbf{r}}_{\text {gloc }} \stackrel{g}{g}$ genotypic correlation of genetic materials, through environments; $\mathrm{CV}_{g} \%=$ genetic coefficient of variation; $\mathrm{CV}_{e} \%=$ experimental variation coefficient; $\mathrm{MG}$ $=$ overall average. 
By the estimates of variance components, it was also possible to verify the existence of genetic variability between genotypes, considering the magnitude of the value of the genetic variance in relation to environmental variance (Table 2). This means that there is high possibility of success in selection for the recommendation of genotypes of coffee, as well as productivity, in different harvests.

It is known that the phenotypic value obtained by measurement in the field results from the genetic value, environmental effect, and interaction of the genotype and the specific environment ( $\mathrm{G} \times \mathrm{E})$. Thus, on the basis of greater or lesser degree of genetic adaptability/ stability of individuals, the variance $\mathrm{G} \times \mathrm{E}$ interaction can inflate the phenotypic expression of a character (Maia et al., 2009). As the value of the variance G x E interaction observed in this study was low in relation to phenotypic variance (Table 2), it is believed that genotypes with good productivity will tend to keep that same response in the crops while maintaining predictability in the face of environmental variations. This trend is also reflected in the high correlation obtained between crops $\left(\hat{\mathrm{r}}_{\text {gloc }}=92.58 \%\right)$. Thus, the study of temporal stability and adaptability by the MHPRVG method becomes relevant to confirm this hypothesis.

It is known that productivity is strongly influenced by environment. Thus, the experimental variation coefficient observed (15.70) is considered satisfactory, indicating that there was good experimental precision in different harvests. Selective accuracy $\left(\hat{\mathrm{r}}_{g} \hat{g}\right.$. $\left.=0.8717\right)$ indicates a strong relationship between predicted and actual values, which results in surety in the selection of agronomically superior genotypes, according to Resende and Duarte (2007). This statistic was preferred to the experimental variation coefficient, because it does not only relies on the magnitude of the residual variance and number of replications, but also on the proportion between the genetic variations and residual nature associated with the character in question (Resende, 2002).

Table 3 shows the ranking of genotypes, considering their average performance, without $\mathrm{G} \times \mathrm{E}$ interaction $(\mathrm{u}+\mathrm{g})$ in the 4 crops evaluated. The genotypes that showed better performance were $9,18,4,10,112014,25$, and 8. Genetic gains obtained through the selection of these genotypes were, respectively, 18.57, 17.33, 16.21, 14.55, 13.94, 11.93, $7.39,7.27$ and $6.22 \%$. Thus, these genotypes show good average performance in the different harvests evaluated, and may be considered for recommendation in the northwestern Rio de Janeiro State. On the other hand, genotypes 17, 12, 21, 22, 7, 5, 15, 24, 3, 1, 19, and 23 showed a negative predicted genotypic effect, indicating that they had lower performance than the overall average, 40.97 (Table 2), and therefore, should not be recommended for this region. According to Maia et al. (2009), the same ranking of genetic averages [predicted genotypic value $(\mathrm{u}+\mathrm{g})$ ] will be expected when the genotypes are evaluated in several harvests, according to the conservative character of the method that would penalize the genotypic values predicted.

The genotypic values predicted for the average crops $(u+g+$ gem $)$, considering the average effect of the interaction, were similar to methods that capitalize adaptability (PRVG) and the adaptability and stability (MHPRVG) at the same time (Table 4). According to Maia et al. (2009), this capitalization of interaction is intrinsic in the choice of genotypes that are more stable and more adapted in the environments evaluated, in this case harvests. Thus, the ordering of the genotypes considering the genotypic values including the interaction was the same as the selection for genetic average without interaction (Table 3). 
Table 3. Estimates of predicted genetic gain for productivity in Coffea arabica genotypes, having considered the average performance in 4 harvests.

\begin{tabular}{|c|c|c|c|c|c|}
\hline \multirow[t]{2}{*}{ Genotype } & \multicolumn{5}{|c|}{ Average components (Individual BLUP) } \\
\hline & $\mathrm{g}$ & $\mu+\mathrm{g}$ & Gain (bags) & New average & $\mathrm{u}+\mathrm{g}+\mathrm{gem}$ \\
\hline 18 & 7.61 & 48.59 & 7.61 & 48.59 & 7.61 \\
\hline 9 & 7.10 & 48.08 & 7.36 & 48.33 & 7.10 \\
\hline 4 & 6.64 & 47.62 & 7.12 & 48.09 & 6.64 \\
\hline 14 & 5.96 & 46.93 & 6.83 & 47.80 & 5.96 \\
\hline 10 & 5.71 & 46.69 & 6.61 & 47.58 & 5.71 \\
\hline 20 & 4.89 & 45.87 & 6.32 & 47.30 & 4.89 \\
\hline 11 & 3.03 & 44.01 & 5.85 & 46.83 & 3.03 \\
\hline 25 & 2.98 & 43.96 & 5.49 & 46.47 & 2.98 \\
\hline 8 & 2.55 & 43.52 & 5.17 & 46.14 & 2.55 \\
\hline 2 & 1.96 & 42.94 & 4.85 & 45.82 & 1.96 \\
\hline 16 & 1.06 & 42.04 & 4.50 & 45.48 & 1.06 \\
\hline 6 & 0.72 & 41.70 & 4.19 & 45.16 & 0.72 \\
\hline 13 & 0.61 & 41.58 & 3.91 & 44.89 & 0.61 \\
\hline 17 & -0.74 & 40.24 & 3.58 & 44.55 & -0.74 \\
\hline 12 & -1.03 & 39.94 & 3.27 & 44.25 & -1.03 \\
\hline 21 & -1.38 & 39.60 & 2.98 & 43.96 & -1.38 \\
\hline 22 & -1.46 & 39.52 & 2.72 & 43.69 & -1.46 \\
\hline 7 & -3.12 & 37.85 & 2.40 & 43.37 & -3.12 \\
\hline 5 & -3.25 & 37.72 & 2.10 & 43.07 & -3.25 \\
\hline 15 & -3.30 & 37.68 & 1.83 & 42.80 & -3.30 \\
\hline 24 & -3.81 & 37.16 & 1.56 & 42.53 & -3.81 \\
\hline 3 & -4.80 & 36.17 & 1.27 & 42.25 & -4.80 \\
\hline 19 & -5.38 & 35.59 & 0.98 & 41.96 & -5.38 \\
\hline 1 & -10.09 & 30.88 & 0.52 & 41.49 & -10.09 \\
\hline 23 & -12.50 & 28.48 & 0.00 & 40.97 & -12.50 \\
\hline
\end{tabular}

Table 4. Stability (MHVG), adaptability (PRVG and PRVGMG) and stability and adaptability (MHPRVG and MHPRVGMG) of genetic values of 25 Coffea arabica genotypes for productivity, predicted by BLUP analysis.

\begin{tabular}{|c|c|c|c|c|c|c|c|}
\hline Genotype & MHVG & Genotype & PRVG & PRVGMG & Genotype & MHPRVG & MHPRVGMG \\
\hline 18 & 48.56 & 18 & 1.19 & 48.84 & 18 & 1.19 & 48.81 \\
\hline 9 & 47.91 & 9 & 1.18 & 48.24 & 9 & 1.18 & 48.24 \\
\hline 4 & 47.50 & 4 & 1.17 & 47.80 & 4 & 1.17 & 47.79 \\
\hline 14 & 46.78 & 14 & 1.15 & 47.09 & 14 & 1.15 & 47.08 \\
\hline 10 & 46.55 & 10 & 1.14 & 46.85 & 10 & 1.14 & 46.84 \\
\hline 20 & 45.71 & 20 & 1.12 & 46.01 & 20 & 1.12 & 46.00 \\
\hline 25 & 43.76 & 11 & 1.08 & 44.05 & 11 & 1.08 & 44.05 \\
\hline 11 & 43.71 & 25 & 1.08 & 44.05 & 25 & 1.07 & 44.04 \\
\hline 8 & 43.30 & 8 & 1.06 & 43.60 & 8 & 1.06 & 43.59 \\
\hline 2 & 42.71 & 2 & 1.05 & 43.00 & 2 & 1.05 & 43.00 \\
\hline 16 & 41.78 & 16 & 1.03 & 42.07 & 16 & 1.03 & 42.07 \\
\hline 6 & 41.45 & 6 & 1.02 & 41.73 & 6 & 1.02 & 41.73 \\
\hline 13 & 41.27 & 13 & 1.01 & 41.59 & 13 & 1.01 & 41.58 \\
\hline 17 & 39.94 & 17 & 0.98 & 40.23 & 17 & 0.98 & 40.22 \\
\hline 12 & 39.61 & 12 & 0.97 & 39.91 & 12 & 0.97 & 39.91 \\
\hline 21 & 39.25 & 21 & 0.97 & 39.55 & 21 & 0.97 & 39.55 \\
\hline 22 & 39.14 & 22 & 0.96 & 39.46 & 22 & 0.96 & 39.45 \\
\hline 7 & 37.48 & 7 & 0.92 & 37.77 & 7 & 0.92 & 37.77 \\
\hline 15 & 37.32 & 5 & 0.92 & 37.61 & 5 & 0.92 & 37.61 \\
\hline 5 & 37.29 & 15 & 0.92 & 37.60 & 15 & 0.92 & 37.60 \\
\hline 24 & 36.79 & 24 & 0.90 & 37.07 & 24 & 0.90 & 37.07 \\
\hline 3 & 35.71 & 3 & 0.88 & 36.03 & 3 & 0.88 & 36.02 \\
\hline 19 & 35.15 & 19 & 0.87 & 35.45 & 19 & 0.87 & 35.44 \\
\hline 1 & 30.20 & 1 & 0.75 & 30.57 & 1 & 0.74 & 30.52 \\
\hline 23 & 27.90 & 23 & 0.69 & 28.17 & 23 & 0.69 & 28.15 \\
\hline
\end{tabular}

$\mathrm{MG}=$ general average in all environments. $\mathrm{MHVG}=$ harmonic mean of the genetic values; PRVG = relative performance of the genetic values; MHPRVG = harmonic mean of the relative performance of the predicted genetic values. 
The G x E interaction can be better understood when the study of adaptability and stability is done, in that it is possible to check the level of response of genotypes to environmental stimulation and maintenance of productivity against environmental variation (Maia et al., 2009). If the most productive genotypes remain better positioned in order in all environments, it means that there was little variation of $\mathrm{G} x \mathrm{E}$ interaction and consequently little environmental influences.

Therefore, the simultaneous selection for yield, stability, and adaptability (MHPRVG), proposed by Resende (2007) by analyzing REML/BLUP, presents some advantages over traditional analyses, as described below: it considers the genotypic effects randomly, providing parameters for adaptability and genotypic stability, provides genotypic values free of environmental factors, and generates results in its own greatness or character range evaluated.

Stability by MHVG indicates the predictability of genotypes in relation to diverse environments. Thus, the more stable genotypes in different harvests were, respectively, 18, 9, 4, $14,10,20,25,11,8$, and 2 (Table 4). For coffee producers, it is key to the recommendation of stable genotypes in different harvests, because of the biennial nature of the crop, which causes temporal variability in the productivity of plants. In this way, more stable genotypes will provide the allocation of better resources and utilization of all infrastructure and manpower, generating more balanced income for producers in different harvests.

However, the prediction of adaptability by Resende (2007) can be performed using PRVG, in the different harvests, relative to the mean of each year. The parameter of adaptability can be understood as the ability of genotypes in responding advantageously to environmental stimuli (Mariotti et al., 1976). In this study, most adapted genotypes were also considered to be more stable, in the following order: $18,9,4,14,10,20,11,25,8$, and 2 (Table 4).

According to Resende (2002), simultaneous selection for harvest, stability and adaptability by the MHPRVG method featuring among others already described the advantage of presenting the genetic gain with the selection by 3 attributes simultaneously.

Thus, the outstanding genotypes in simultaneous selection considering the productivity and stability and genetic adaptability parameters (MHPRVG) were respectively: 18, 9, 4, $14,10,20,11,25,8$, and 2 . Maintaining the ordering of the selected genotypes in relation to 3 parameters was due to a high positive correlation (Table 1) between genotypic behavior of clones in the different harvests. These results make it possible to indicate new genotypes for planting in the northwestern Rio de Janeiro State, for example, 18, 9, 4, and 14. Currently, the genotype of most coffee planted in the northwestern Rio de Janeiro State is 17, which ranked lower. Thus, it is clear that further study should be conducted to ensure indication of productive and stable genotypes adapted to Rio de Janeiro, thus promoting the expansion and strengthening of coffee production in this State.

\section{CONCLUSIONS}

The average heritability of genotypes showed high magnitude, indicating good prospects of success in the selection and assignment of genotypes with high accuracy. There was little variation in the ordering of genotypes throughout the environments, indicating little influence of harvests on the performance of the genotypes. The genotypes $18,9,4,14$, and 10 showed high productivity, stability, and predicted adaptability as the main options recommended for planting in the region. The evaluation methods of productivity, stability, and 
adaptability, PRVG, MHVG, and MHPRVG must be part of the selection criteria for recommendation of genotypes of coffee for commercial plantations.

\section{REFERENCES}

Centro do Comércio de Café do Rio de Janeiro (2012). Café no Rio: Evolução da Produção. Available at [http://www. cccrj.com.br/rio/producao.htm]. Accessed September 27, 2012.

Companhia Nacional de Abastecimento (2012). Café Brasil: Série Histórica de Produtividade. Available at [http://www. conab.gov.br/conabweb/download/safra/]. Accessed September 25, 2012.

Cucolotto M, Pípolo VC, Garbuglio DD, Fonseca Junior NS, et al. (2007). Genotype x environment interaction in soybean: evaluation through three methodologies. Crop Breed. Appl. Biotechnol. 7: 270-277.

Maia MCC, Resende MDV, Paiva JR, Cavalcanti JJV, et al. (2009). Seleção simultânea para produção, adaptabilidade e estabilidade genotípicas em clones de cajueiro, via modelos mistos. Pesq. Agropec. Trop. 39: 43-50.

Mariotti JA, Oyarzabal ES, Osa JM, Bulacio ANR, et al. (1976). Análisis de estabilidad y adaptabilidad de genotipos de cana de azúcar. I. Interacciones dentro de un localidad experimental. Rev. Agron. Noroeste Argentino 13: 105-127.

Martorano LG, Rossiello ROP, Meneguelli NA, Lumbreras J F, et al. (2003). Aspectos Climáticos do Noroeste Fluminense, RJ. Documento, 43. Embrapa Solos, Rio de Janeiro.

Matiello JB, Santinato R, Garcia AWR, Almeida SR, et al. (2005). Cultura de Café no Brasil: Novo Manual de Recomendações. 2nd edn. Bom Pastor, Rio de Janeiro.

Resende MDV (2002). Genética Biométrica e Estatística no Melhoramento de Plantas Perenes. Embrapa Informação Tecnológica, Brasília.

Resende MDV (2004). Métodos Estatísticos Ótimos na Análise de Experimentos de Campo. Embrapa Florestas, Colombo.

Resende MDV (2007). Matemática e Estatística na Análise de Experimentos e no Melhoramento Genético. Embrapa Florestas, Colombo.

Resende MDV and Duarte JB (2007). Precisão e controle de qualidade em experimentos de avaliação de cultivares. Pesq. Agropec. Trop. 37: 182-194.

Rosado AM, Rosado TB, Alves AA, Laviola BG, et al. (2012). Seleção simultânea de clones de eucalipto de acordo com produtividade, estabilidade e adaptabilidade. Pesq. Agropec. Bras. 47: 964-971.

Thomaziello RA, Fazuoli LC, Pezzopane JRM, Fahl JI, et al. (2000). Café Arábica: Cultura e Técnica de Produção. 2nd edn. Instituto Agronômico de Campinas, Campinas.

Verardi CK, Resende MDV, Costa RB and Gonçalves PS (2009). Adaptabilidade e estabilidade da produção de borracha e seleção em progênies de seringueira. Pesq. Agropec. Bras. 44: 1277-1282. 